SAKAI SAMBAYAN — Jurnal Pengabdian kepada Masyarakat

\title{
SOSIALISASI IMPLEMENTASI BUAH-BUAHAN SEBAGAI SUMBER ENERGI LISTRIK UNTUK PENGAYAAN PELAJARAN FISIKA BAGI SISWA SMA YP UNILA
}

\author{
Yetti Yuniati*, Sri Purwiyanti, Yul Martin \\ Jurusan Teknik Elektro Universitas Lampung, Bandar Lampung \\ Jl. Prof. Sumantri Brojonegoro No.1 Bandar Lampung 35145 \\ Penulis Korespodensi : yetti.yuniati@eng.unila.ac.id
}

\begin{abstract}
Abstrak
Listrik merupakan kebutuhan bagi masyarakat luas. Kebutuhan akan sumber energi baru dan terbarukan saat ini terus meningkat. Salah satu solusi dari masalah tersebut dapat dilakukan melalui pemanfaatan energi dari buah-buahan yang banyak tersedia dan belum dimanfaatkan secara optimal. Energi dari buah-buahan tersebut selain merupakan energi yang ramah lingkungan juga energi yang dapat diperbaharui. Konsep tentang listrik dan perhitunganperhitungan yang ada didalamnya, masih belum digemari oleh seluruh siswa. Apalagi, bila materi terkait energi dan listrik tersebut disampaikan dengan cara yang monoton, yaitu guru menjelaskan dan para siswa menyimak. Untuk itu dibutuhkan pengayaan materi pembelajaran agar lebih menarik, mudah dipahami dan siswa terlibat aktif didalamnya. Buah dan sayur yang digunakan pada saat praktik antara lain: pisang, apel, jeruk nipis dan kentang. Metode yang digunakan pada kegiatan Pengabdian ini meliputi: sosialisasi tentang konsep listrik, praktik membuat rangkaian listrik secara lansung menggunakan buah-buahan sebagai sumber energi, diskusi dan evaluasi pelaksanaan kegiatan. Dari hasil pengukuran didapatkan apel memiliki tegangan yang paling tinggi yaitu sebesar 0,61 Volt.
\end{abstract}

Kata kunci: Buah, Listrik, Pembelajaran, Pengukuran, Renewable Energy

\section{Pendahuluan}

Konsep tentang listrik dan perhitunganperhitungan yang ada didalamnya, masih sulit dipahami oleh seluruh siswa. Apalagi, bila materi terkait energi dan listrik tersebut disampaikan dengan cara konvensional, yaitu guru menjelaskan dan para siswa menyimak. Untuk itu dibutuhkan pengayaan materi pembelajaran agar lebih menarik, mudah dipahami dan siswa terlibat aktif didalamnya.

Perumusan Masalah kegiatan ini terdiri dari:

a. Apakah yang dimaksud dengan Listrik, sumber listrik, arus listrik, tegangan listrik?

b. Bagaimana proses listrik dapat mengalir pada rangkaian?

c. Bagaimana buah-buahan dapat menjadi salah satu penghasil energi listrik dari buah-buahan?

d. Bagaimana cara mengukur level tegangan pada sample buah-buahan?

Tujuan kegiatan ini adalah membekali para siswa tentang pengetahuan dibidang Listrik, Energi dari buah-buahan dan aplikasinya.
Tujuan besar ini dijabarkan dalam beberapa tujuan khusus, yaitu:

1. Mengetahui perkembangan bidang kelistrikan, energi alternatif, dan aplikasinya.

2. Mampu membuat rangkaian listrik menggunakan catu daya dari buah-buahan dan mengukur tegangan yang dihasilkan.

3. Mampu menumbuhkan minat dan kreatifitas para siswa untuk mempelajari dan menganalisis materi konsep tentang listrik.

Manfaat yang dapat diperoleh dari pelaksanaan kegiatan ini adalah:

1. Meningkatnya pengetahuan para siswa tentang listrik, sumber energi dari buahbuahan dan aplikasinya.

2. Para siswa mengetahui dan memahami tentang komponen-komponen yang digunakan pada saat praktik dan cara kerja rangkaian yang dibuat.

3. Para siswa yang menjadi peserta dapat mengimplementasikan pengetahuan yang 
telah didapat tersebut dengan cara membuat aplikasi rangkaian listrik sederhana menggunakan catu daya dari buah-buahan.

\section{Kajian Teoritik}

Pada dasarnya, energi listrik dapat diperoleh dari berbagai sumber termasuk buah dan sayur. Energi listrik dapat dihasilkan dari buah-buahan khususnya buah yang mengandung banyak asam sitrat [1].

Penelitian tentang kelistrikan buah ini merupakan pengembangan hasil penelitian dari Alexander Volta. Dari penelitian volta disebutkan bahwa jika suatu deretan zat dimasukan ke larutan asam atau garam maka akan melepaskan muatanmuatan listrik. Berdasarkan teori itulah percobaan dengan mencelupkan dua logam yang termasuk deret volta seperti ujung kabel yang dihubungkan dari zat asam ke multimeter, sehingga multimeter tersebut akan menunjukkan besar tegangan listrik ataupun arus yang diperoleh dari percobaan tersebut [2].

Arus listrik didefinisikan sebagai jumlah muatan elektron yang mengalir suatu penghantar per satuan waktu [3].

$\mathrm{I}=\mathrm{Q} / \mathrm{t}$ atau $\mathrm{Q}=\mathrm{It}$

dengan $Q=$ jumlah muatan elektron yang mengalir (Coulomb)

$\mathrm{t}=$ waktu (sekon)

$\mathrm{I}=$ kuat arus (ampere)

Komponen sebuah rangkaian listrik atau rangkaian elektronik dapat dihubungkan dengan berbagai cara. Dua tipe paling sederhana adalah rangkaian seri dan parallel. Rangkaian yang disusun secara sejajar disebut rangkaian seri, sedangkan rangkaian yang disusun secara berderet disebut rangkaian paralel.

Komponen yang tersusun seri akan terhubung melalui satu jalur, sehingga aliran arus listrik akan mengalir ke semua komponen [5].

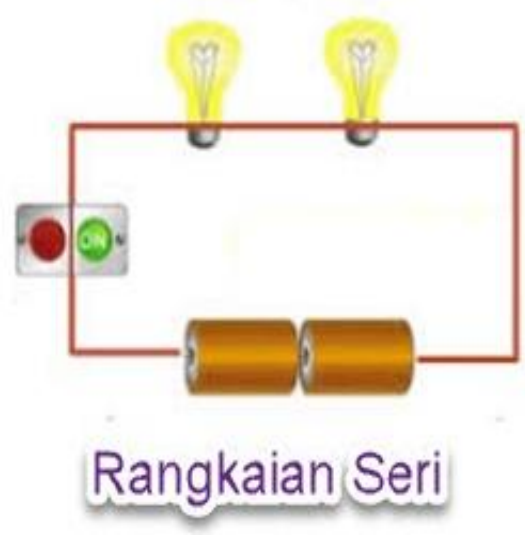

Gambar 1. Contoh Rangkaian Seri

Pada rangkaian paralel, tegangan yang melewati tiap komponen adalah sama, dan total arus adalah jumlah arus yang melewati tiap komponen [4].

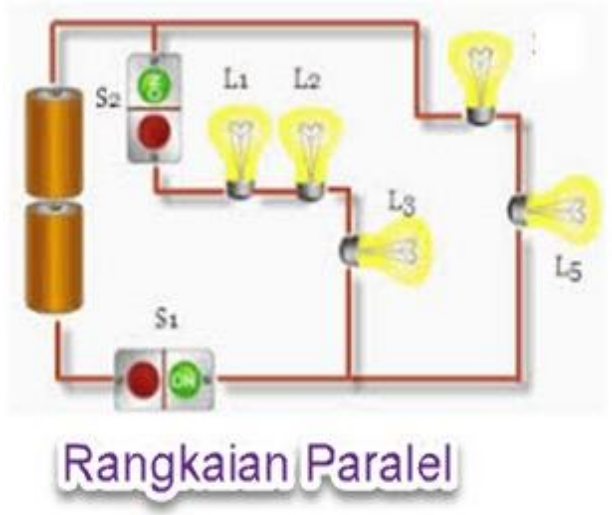

Gambar 2. Contoh Rangkaian Paralel

\section{Materi dan Metode}

Bagian ini berisi kerangka pemecahan masalah, realisasi pemecahan masalah, khalayak sasaran dan metode yang digunakan dalam pengabdian kepada masyarakat.

Rencana pemecahan masalah yang termasuk dalam penerapan ilmu pengetahuan dan teknologi untuk peningkatan pemahaman tentang konsep listrik ini adalah:

a) Mengadakan sosialisasi tentang perkembangan teknologi kelistrikan dan aplikasinya.

b) Mengadakan kuliah singkat tentang listrik, sumber energi dari buah-buahan beserta komponen-komponennya. 
c) Melakukan praktik untuk mengimplementasikan pengetahuan yang telah didapat. Dalam tahap ini, peserta dilatih untuk melakukan ujicoba secara lansung, sehingga dapat diimplementasikan dalam proses belajar.

d) Mengadakan diskusi terbuka bagi para peserta mengenai permasalahan yang ada ketika melakukan ujicoba secara lansung.

Ketiga rencana pemecahan masalah tersebut dijabarkan dalam Tabel 1 berikut ini:

Tabel 1. Rencana Pemecahan Masalah

\begin{tabular}{|l|l|l|}
\hline \multicolumn{1}{|c|}{ Kondisi Sebelum } & \multicolumn{1}{|c|}{ Bentuk Kegiatan } & \multicolumn{1}{c|}{ Kondisi Sesudah } \\
\hline $\begin{array}{l}\text { Peserta masih belum } \\
\text { memahami apa yang } \\
\text { dimaksud sumber energi } \\
\text { dari buah-buahan, dan } \\
\text { aplikasinya. }\end{array}$ & $\begin{array}{l}\text { Sosialisasi konsep atau } \\
\text { pengantar tentang } \\
\text { sumber energi dari buah- } \\
\text { buahan beserta } \\
\text { aplikasinya. }\end{array}$ & $\begin{array}{l}\text { Peserta memahami } \\
\text { tentang perkembangan } \\
\text { sumber energi dari buah- } \\
\text { buahan dan aplikasinya } \\
\text { terutama untuk } \\
\text { menunjang proses } \\
\text { pengembangan minat } \\
\text { pada teknologi robotika }\end{array}$ \\
\hline $\begin{array}{l}\text { Peserta masih belum } \\
\text { memahami tentang } \\
\text { rangkaian listrik dan } \\
\text { penggunaan komponen- } \\
\text { komponen elektronika di } \\
\text { dalam rangkaian }\end{array}$ & $\begin{array}{l}\text { Diskusi langsung tentang } \\
\text { jenis-jenis rangkaian } \\
\text { listrik serta bagaimana } \\
\text { penggunaan komponen- } \\
\text { komponen elektronika di } \\
\text { dalam rangkaian }\end{array}$ & $\begin{array}{l}\text { Peserta mengetahui dan } \\
\text { memahami tentang jenis- } \\
\text { jenis rangkaian listrik } \\
\text { dan penggunaan } \\
\text { komponen-komponen } \\
\text { elektronika di dalam }\end{array}$ \\
\hline $\begin{array}{l}\text { Peserta tidak mengetahui } \\
\text { cara } \\
\text { mengimplementasikan } \\
\text { komponen-komponen } \\
\text { elektronika pada saat } \\
\text { ujicoba/praktek secara } \\
\text { lansung }\end{array}$ & $\begin{array}{l}\text { Pelatihan cara } \\
\text { penggunaan, merakit dan } \\
\text { menguji rangkaian } \\
\text { elektronika sederhana } \\
\text { serta tahapan-tahapan } \\
\text { yang harus dilakukan } \\
\text { agar dapat } \\
\text { mengimplementasikan } \\
\text { komponen-komponen } \\
\text { elektronika tersebut } \\
\text { secara lansung melalui } \\
\text { praktik yang } \\
\text { mendukung. }\end{array}$ & $\begin{array}{l}\text { Peserta dapat } \\
\text { mengimplementasikan } \\
\text { pengetahuan tentang } \\
\text { sumber energy dari } \\
\text { buah-buahan tersebut } \\
\text { sebagai proses } \\
\text { pengayaan pembelajaran } \\
\text { di kelas }\end{array}$ \\
\hline
\end{tabular}

Materi pokok yang diberikan adalah:

- Pengantar tentang perkembangan listrik, sumber energy dari buah-buahan dan aplikasinya,

- Pengantar tentang jenis-jenis rangkaian listrik dan aplikasinya.

- Komponen-komponen elektronika yang digunakan pada rangkaian/perakitan rangkaian listrik

- Fungsi dari masing-masing komponen elektronika

- Praktek tahapan-tahapan untuk membuat/merakit rangkaian elektronika sederhana sebagai bagian pengayaan materi dalam proses pembelajaran di kelas melalui praktik lansung.
Dalam sesi diskusi, peserta akan diberikan kesempatan bertanya maupun memberitakan pendapat tentang materi-materi yang telah diberikan sebelumnya. Sesi diskusi ini juga dapat dijadikan tolak ukur untuk melihat keikutsertaan atau keterlibatan para peserta. Sasaran utama yang dianggap sangat strategis dalam kegiatan ini adalah para siswa di SMA YP Unila. Jumlah peserta direncanakan sebanyak 20 - 30 orang.

\section{Hasil dan Pembahasan}

Indikator keberhasilan dari pelatihan ini adalah:

1. Peserta dapat memahami tentang perkembangan robotika, UAV dan aplikasinya

2. Peserta dapat menyebutkan apa saja jenis-jenis UAV yang ada

3. Peserta dapat dapat mengimplementasikan dan merakit sendiri rangkaian elektronika sederhana sebagai bagian pengayaan materi melalui simulasi/demo.

Semuanya dapat diukur melalui pengisian kuesioner ataupun test sebelum dan sesudah kegiatan berlangsung.

Tabel 2. Hasil Evaluasi

\begin{tabular}{|c|c|c|c|c|c|c|}
\hline \multirow{3}{*}{ No.Soal } & \multicolumn{6}{|c|}{ HASIL KUESIONER } \\
\cline { 2 - 7 } & \multicolumn{3}{|c|}{ Sebelum Kegiatan } & \multicolumn{3}{c|}{ Sesudah Kegiatan } \\
\cline { 2 - 7 } & Jumlah peserta menjawab : & \multicolumn{3}{c|}{ Jumlah peserta menjawab : } \\
\cline { 2 - 7 } & a & b & c & a & b & c \\
\hline 1 & 2 & 28 & 0 & 28 & 2 & 0 \\
\hline 2 & 0 & 30 & 0 & 23 & 7 & 0 \\
\hline 3 & 0 & 30 & 0 & 30 & 0 & 0 \\
\hline 4 & 0 & 20 & 10 & 25 & 5 & 0 \\
\hline 5 & 0 & 30 & 0 & 30 & 0 & 0 \\
\hline 6 & 5 & 20 & 5 & 30 & 0 & 0 \\
\hline
\end{tabular}

Peserta mengikuti pelaksanaan pengisian kuesioner sebelum dan sesudah pelaksanaan pemberian materi dan diskusi berjumlah 30 (tiga puluh) orang. Setelah penyampaian materi dan diskusi, terlihat adanya peningkatan pengetahuan peserta sekitar 97\%. Hal ini disebabkan ada beberapa hal dalam materi yang masih belum dimengerti oleh peserta.

Tabel 3. Data Hasil Pengukuran Para Siswa-Siswi SMA YP Unila

\begin{tabular}{|l|c|c|c|}
\hline \multicolumn{4}{|c|}{ Kelompok1 } \\
\hline Sample & Tegangan (V) & Kombinasi & Tegangan (V) \\
\hline Apel & 0,61 & & \\
\hline Kentang & 0,45 & & \\
Pisang & 0,37 & Hubung Seri & 1,42 \\
Jeruk Nipis & 0,41 & & \\
\hline
\end{tabular}

\begin{tabular}{|l|c|c|c|}
\hline \multicolumn{4}{|c|}{ Kelompok2 } \\
\hline Sample & Tegangan (V) & Kombinasi & Tegangan (V) \\
\hline Pisang & 0,53 & & \\
\hline Apel & 0,38 & & \\
Kentang & 0,49 & Hubung Seri & 1,53 \\
\hline Lemon & 0,44 & & \\
\hline
\end{tabular}




\begin{tabular}{|c|c|c|c|}
\hline \multicolumn{4}{|c|}{ Kelompok3 } \\
\hline Sample & Tegangann (VV & Kombinasi & Tegangan (VV \\
\hline Pisgng & 0,55 & \multirow{4}{*}{ Hubung Seri } & \multirow{4}{*}{148} \\
\hline Kentang & 0,43 & & \\
\hline |eronk Nipis & 0,35 & & \\
\hline Apel & 0,45 & & \\
\hline
\end{tabular}

\begin{tabular}{|l|c|c|c|}
\hline \multicolumn{4}{|c|}{ Kelompok4 } \\
\hline Sample & Tegangan (V) & Kombinasi & Tegangegn (V) \\
\hline Apel & 0,5 & & \\
\hline Kentanng & 0,47 & & \\
\hline Pisang & 0,39 & Hubung Seri & 1,37 \\
\hline Lerul Nipis & 0,43 & & \\
\hline
\end{tabular}

\section{Kesimpulan dan Saran}

\section{A. Kesimpulan}

Kegiatan pengabdian kepada masyarakat dengan tema "Pemanfaatan Buah-Buahan Sebagai Sumber Energi Listrik Bagi Siswa SMA YP Unila Bandar Lampung" ini sangat bermanfaat untuk meningkatkan minat para siswa untuk mengikuti lebih memahami konsep tentang listrik dan energi alternatif. Berdasarkan hasil pelaksanaan kegiatan yang telah dilakukan, dapat ditarik beberapa kesimpulan sebagai berikut:

1. Para siswa mengetahui perkembangan bidang kelistrikan, energi alternatif, dan aplikasinya.

2. Para siswa mengetahui komponen-komponen dari rangkaian listrik menggunakan catu daya dari buah-buahan.

3. Para siswa mengetahui cara penerapan komponen-komponen elektronika tersebut di dalam rangkaian listrik
4. Mampu menumbuhkan minat dan kreatifitas para siswa untuk mempelajari dan mengembangkan sumber energi dari buahbuahan dan aplikasinya.

\section{B. Saran}

Diharapkan agar kegiatan ini dapat terus dilakukan dan dikembangkan untuk kesempatan lain dengan variasi buah dan sayur serta metode yang lain.

\section{Daftar Pustaka}

Kartawidjaya, M, Abdurrocman, A dan Rumeksa, A. 2008. Pencarian Parameter Bio-Baterai Asam Sitrat (C6H8O7). Prosiding Seminar Nasional Sains dan Teknologi -II :105-115.

Kholida, H., \& Pujayanto, P. 2015. Hubungan Kuat Arus Listrik dengan Keasaman Buah Jeruk dan Mangga. Prosiding Seminar Nasional Fisika dan Pendidikan Fisika (Vol. 6, No. 1).

Jatmiko, B, dan Achmadi, H.R. 2004. Listrik Dinamis. Modul. Depdiknas.

Resnick, Robert and Halliday, David (1966), Physics, Vol I and II, Combined edition, Wiley International Edition, Library of Congress Catalog Card No. 66-11527.

Smith, R.J. (1966), Circuits, Devices and Systems, Wiley International Edition, New York. Library of Congress Catalog Card No. 6617612. 